\title{
PENGOLAHAN SAMPAH ORGANIK PERKOTAAN MENGGUNAKAN LARVA BLACK SOLDIER FLY (Hermetia illucens)
}

\section{Municipal Organic Waste Recycling Using Black Soldier Fly Larvae (Hermetia illucens)}

\author{
Lena Monita ${ }^{\mathrm{a}}$, Surjono Hadi Sutjahjo ${ }^{\mathrm{b}}$, Akhmad Arif Amin ${ }^{\mathrm{c}}$, Melta Rini Fahmi ${ }^{\mathrm{d}}$ \\ ${ }^{a}$ Program Studi Pengelolaan Sumberdaya Alam dan Lingkungan Sekolah Pascasarjana, Institut Pertanian Bogor, \\ Kampus IPB Baranangsiang, Bogor 16143 _monita.sihotang@gmail.com \\ ${ }^{b}$ Departemen Agronomi dan Hortikultura, Fakultas Pertanian, Institut Pertanian Bogor, Kampus IPB Darmaga, \\ Bogor 16680 \\ ${ }^{c}$ Departemen Ilmu Penyakit Hewan dan Kesehatan Masyarakat Veteriner (IPHK), Fakultas Kedokteran Hewan, \\ Institut Pertanian Bogor, Kampus IPB Darmaga, Bogor 16680 \\ ${ }^{d}$ Balai Penelitian dan Pengembangan Budidaya Ikan Hias, Pancoran Mas, Depok 16436
}

\begin{abstract}
Black soldier fly (BSF) larvae (Hermetia illucens) can be used as insect based municipal organic waste recycling technology. The purpose of this research was to examine the utilization of BSF larvae as bio-processors of organic waste in order to produce compost and nutritious larvae biomass. Larvae feeds as treatments of experiment consist of restaurant organic waste mixed with fish silage $6 \%$ as treatment $A$, restaurant organic waste with dairy blood waste $6 \%$ as treatment $B$, and restaurant organic waste as treatment $C$. The result of this research showed that the highest larvae growth according to its length, width and body weigth was resulted by treatment B, followed by treatments $A$ and $C$. Total metamorphic development time from egg to imago was 35 days; comprised of as larvae, prepupa, pupa, and imago for 12-13, 6, 6, and 15 days, respectively. Proximate analysis showed that BSF larvae had protein content 33.31 to $33.88 \%$, and fat content 30.07 to $34.39 \%$. Final solid residues of the three treatments was ranged from 90.3-90.6\% after 10-11 days of bio-processing.
\end{abstract}

Keywords: Black soldier fly larvae, compost, restaurant organic waste, proximate analysis

(Diterima: 03-04-2017; Disetujui: 04-06-2017)

\section{Pendahuluan}

Undang-undang Nomor 18 Tahun 2008 menyebutkan bahwa sampah adalah sisa kegiatan sehari-hari manusia dan/atau proses alam yang berbentuk padat; adapun pengelolaan sampah merupakan kegiatan yang sistematis, menyeluruh, dan berkesinambungan yang meliputi pengurangan dan penanganan sampah. Saat ini hampir semua negara berkembang memiliki permasalahan dalam pengelolaan sampah (Dortman, 2015) termasuk di Indonesia.

Kementerian Lingkungan Hidup dan Kehutanan (KLHK) menyebutkan bahwa jumlah timbulan sampah di Indonesia telah mencapai 175.000 ton/hari atau setara 64 juta ton/tahun dengan pengelolaan diangkut dan ditimbun di TPA sebanyak 69\%, dikubur $10 \%$, dikompos dan didaur ulang 7\%, dibakar 5\%, dan sisanya tidak terkelola 7\%. Mengacu pada data tersebut terlihat saat ini pengelolaan sampah masih terkonsentrasi di Tempat Pemrosesan Akhir (TPA) sampah tanpa melalui proses 3R (reduce, recycle, reuse) di sumber dengan melibatkan partisipasi masyarakat. Kondisi ini menjadi faktor utama beban TPA menjadi berat dan umur penggunaannya semakin pendek (Suyanto et al., 2015).

Berdasarkan komposisinya maka sampah terbagi menjadi jenis sampah organik $60 \%$, plastik $15 \%$, kertas $10 \%$, dan lainnya (seperti logam, kaca, kain, kulit)
15\% (KLHK, 2015). Sampah organik didominasi oleh sampah makanan (produk hewani dan nabati), sayursayuran, buah-buahan, limbah ikan, limbah pertanian dan perkebunan, limbah kayu, daun-daunan, ranting, serta kotoran hewan dan manusia. Sampah organik tersebut apabila tidak ditangani dengan baik dapat menjadi sumber penyebab penyakit, sumber pencemar yang menghasilkan limbah cairan lindi yang dapat mencemari air tanah, dan gas menghasilkan metan mencemari udara penyebab pemanasan global sertadapat menimbulkan bau busuk.

Menurut Suriawiria (2003) sampah organik merupakan jenis sampah yang tersusun oleh senyawa organik dan bersifat degradable yaitu secara alami dapat/mudah diuraikan oleh jasad hidup (khususnya mikroorganisme). Sampah organik tersebut dibagi menjadi sampah organik lunak dan sampah organik padat/keras. Pada umumnya, sampah organik lunak didaurulang dengan teknologi pengomposan menghasilkan kompos (Gani, 2007) dan anaerobic digestion menghasilkan biogas (Davis et al., 2014) dengan melibatkan aktivitas mikroorganisme.

Sampah organik padat/keras sulit diurai oleh mikroorganisme sehingga perlu dikelola dengan teknologi konversi termal meliputi pirolisis, gasifikasi dan insenerasi menghasilkan energi listrik, gas, cair (bio-oil dan asap cair) dan arang (Widyawidura dan Pongoh, 2016; Naryono et al., 2015; Wibowo, 2013; Gani, 2007). Namun, dalam penerapan teknologi- 
teknologi tersebut memiliki banyak tantangan dan kendala terutama komposisi sampah Indonesia masih didominasi sampah organik dengan kadar air 65-75\% (Sudrajat, 2006). Pada penerapan skala besar harus dipikirkan biaya investasi dan pengoperasian yang tinggi, ketersediaan peralatan, ketersediaan sumber daya manusia pengelola, dan emisi polutan udara (Cheng dan Hu, 2010).

Saat ini, pengolahan sampah organik berbasis serangga dengan memanfaatkan larva black soldier fly (BSF), Hermetia illucens L. (Diptera: Stratiomyidae) belum populer dan belum banyak dikaji di Indonesia. Larva BSF merupakan strategi inovatif dan salah satu metode berkelanjutan untuk pengelolaan sampah organik yang dapat mengurangi beban TPA sampah (Nguyen et al., 2015; Gabler, 2014) dan dapat membuka peluang ekonomi baru yang menguntungkan bagi penduduk kota dan pengusaha skala kecil di negara-negara berkembang (Diener et al., 2011a). Larva BSF sangat aktif makan berbagai bahan organik, seperti buah-buahan dan sayuran, sampah pasar, sampah dapur, limbah ikan, bungkil kelapa sawit, dan kotoran hewan ternak dan manusia (Nguyen et al., 2015; Fahmi, 2015; Diener et al., 2011b; St-Hilaire et al., 2007a; Newton et al., 2005a), sehingga dikelompokkan sebagai agen biokonversi (Fahmi, 2015). Kemampuan larva BSF dalam mereduksi sampah organik telah dilaporkan sebesar 66.4-78.9\% (Diener et al., 2011a), 85\% BB dan 70\% BK (Dortmans, 2015), 44-94 \% (Bonso, 2013) dan 44-56\% (Alvarez, 2012).

Selain kemampuan larva BSF dalam mereduksi sampah, tahap akhir larva yang disebut prepupa dapat dipanen sendiri (self harvesting) menghasilkan nilai tambah yang tinggi (Diener et al., 2011a) yaitu mengandung protein $40 \%$ dan lemak $30 \%$ yang digunakan sebagai pakan ikan dan hewan ternak pengganti tepung ikan (Diener et al. 2009a, Newton et al. 2005b, St-Hilaire et al. 2007b). Kandungan nutrisi larva tersebut dapat dijadikan sebagai bahan baku pakan alami mengingat sampai saat ini Indonesia masih mengimpor pakan ikan terutama tepung ikan dan tepung udang walaupun telah mengalami penurunan sebesar 15.56\% (BPS, 2012). Pada sisi lain, kandungan lemak larva BSF sebesar 30\% memiliki potensi menjadi bahan baku untuk produksi biodiesel sebagai energi alternatif (Li et al., 2011; Zheng et al., 2012). Residu sampah yang dihasilkan dapat digunakan sebagai kompos dan amandemen tanah di bidang pertanian (Gabler, 2014; Alvarez, 2012; Diener et al., 2011b). Selain residu padat juga dapat dihasilkan pupuk cair dalam pengolahan limbah lindi (Alattar, 2012).

Penelitian ini bertujuan mengkaji pemanfaatan larva BSF dalam mengolah sampah organik perkotaan yang digunakan sebagai media pertumbuhan dan perkembangannya.

\section{Bahan dan Metode}

\subsection{Lokasi dan Waktu Penelitian}

Penelitian dilakukan di kandang larva dan serangga BSF Balai Penelitian dan Pengembangan Budidaya Ikan Hias Depok pada bulan Mei 2016 sampai Juli 2016. Uji proksimat larva dilakukan di Pusat Penelitian Sumberdaya Hayati dan Bioteknologi Lembaga Penelitian dan Pemberdayaan Masyarakat IPB.

\subsection{Alat dan Bahan}

Peralatan yang digunakan antara lain fiber glass (4 x $1 \mathrm{~m}$ ) sebagai wadah untuk kultur BSF dari telur sampai larva berumur 1 minggu, bak beton (diameter $317 \mathrm{~cm}$ dan tinggi $47 \mathrm{~cm}$ ) sebagai wadah perlakuan, tong dengan volume $150 \mathrm{~L}$ sebagai wadah fermentasi silase ikan, wadah plastik (diameter $19 \mathrm{~cm}$, tinggi 10 $\mathrm{cm}$ ) sebagai wadah BSF bertelur, kain penutup bak, kain net insect dan pipa paralon untuk pembuatan kandang baru imago BSF, termometer dan $\mathrm{pH}$ media, thermo-hygrometer (pengukur suhu dan kelembaban udara), milimeter block, spatula, kamera digital, timbangan digital, timbangan analitik, cawan petri, dan sekop.

Bahan yang digunakan adalah sampah organik perkotaan berupa sampah restoran diperoleh dari Unit Pengolahan Sampah (UPS) Merdeka 1 Depok. Limbah ikan diperoleh dari Pasar Kemiri Depok, dan darah sapi segar diperoleh dari Rumah Potong Hewan (RPH) Depok. Palm Kernel Meal (PKM) diperoleh dari Balai Riset Budidaya Ikan Hias Depok.

\subsection{Metode}

\subsubsection{Persiapan Penelitian}

Persiapan penelitian diawali dengan kultur larva muda. Larva muda didapatkan dengan mengoleksi telur dari kandang serangga dan pembuatan media pertumbuhan larva dengan cara PKM kering dicampur dengan air (1:2) kemudian difermentasi selama 3 hari. Bobot PKM kering sebesar $15 \mathrm{~kg}$ dan air $30 \mathrm{~L}$. Selanjutnya, sebanyak 20 gram telur BSF dimasukkan ke dalam 3 wadah fiber glass berisi PKM. Telur BSF menetas setelah 1 hingga 2 hari sejak telur diletakkan dan memasuki tahap aktif makan. Larva yang telah menetas memiliki warna tubuh putih. Larva muda dipelihara selama 6 hari setelah penetasan untuk digunakan sebagai biomassa pengolahan sampah organik.

Persiapan media tumbuh larva sampai pupa diawali dengan mengambil sampah organik dari beberapa restoran yang ada di Depok dibawa ke lokasi penelitian. Selanjutnya, dilakukan pemilahan sampah antara organik dan anorganik yang masih tercampur. Sampah organik yang telah terpilah kemudian diaduk sampai merata, ditimbang dan dimasukkan ke dalam 
wadah perlakuan. Sampah organik yang digunakan masih segar (one night) untuk menghindari kontaminasi lalat lain, tidak dicacah dan memiliki berbagai jenis sayur-sayuran, buah-buahan, kulit buah-buahan, daging, sisa makanan, sisa hasil masakan, bumbubumbu dapur, ampas kelapa, nasi dan rerotian.

Pakan tambahan sebagai enrichment menggunakan silase ikan dan limbah darah sapi. Pembuatan silase ikan diawali dengan pengambilan limbah ikan dari pasar Kemiri Depok kemudian difermentasi dengan asam formiat dan didiamkan selama kurang lebih 2 minggu. Sedangkan limbah darah sapi diambil dari Rumah Potong Hewan (RPH) Depok, kemudian dimasukkan ke dalam plastik putih dan disimpan dalam freezer untuk digunakan selama penelitian. Pakan tersebut diberikan ketika larva dipindahkan ke wadah perlakuan.

\subsubsection{Rancangan Percobaan}

Penelitian ini menggunakan Rancangan Acak Kelompok 1 faktor dengan 3 taraf perlakuan yaitu Perlakuan A terdiri dari $300 \mathrm{~kg}$ sampah organik restoran ditambah $6 \%$ silase ikan, Perlakuan B $300 \mathrm{~kg}$ sampah organik restoran ditambah $6 \%$ darah sapi dan Perlakuan C $300 \mathrm{~kg}$ sampah organik restoran tanpa penambahan. Hari (umur larva BSF) digunakan sebagai kelompok. Pengambilan sampel setiap 2 hari sekali dengan mengambil larva secara acak dan ditimbang sebanyak $1 \mathrm{~g}$.

Larva muda berumur 6 hari dipindahkan ke dalam masing-masing wadah perlakuan. Selama proses dekomposisi, dilakukan pengukuran suhu dan $\mathrm{pH}$ media serta suhu dan kelembaban udara. Sementara pertumbuhan larva hingga pupa diamati dengan mengukur panjang, lebar dan bobot tubuh. Larva memasuki fase prepupa sebanyak 40-50\% dapat dipanen, ditimbang dan dicatat kemudian dipindahkan ke fiber glass sebagai wadah untuk memasuki fase pupa. Pada saat fase pupa lebih dari $50 \%$, diambil secara acak kemudian ditimbang sebanyak $1 \mathrm{~kg}$ dan dimasukkan ke wadah plastik hitam sebagai wadah pupa hingga menetas menjadi imago. Residu yang dihasilkan dari proses dekomposisi ditimbang dan dicatat.

Pengamatan perkembangan imago BSF diawali dengan membuat kandang baru berukuran 80 x $80 \mathrm{x}$ $100 \mathrm{~cm}^{3}$ dengan bahan berupa pipa paralon dan net insect (jaring nilon) berwarna putih. Kandang baru tersebut ditempatkan dalam kandang besar serangga. Pupa sebanyak $1 \mathrm{~kg}$ dimasukkan ke dalam kandang baru untuk mengetahui perkembangan imago, aktivitas kawin dan bertelur.

Pupa menetas menjadi imago muda memasuki fase serangga dewasa dan seiring berjalannya waktu imago terbang, melakukan aktivitas kawin dan bertelur. Bobot telur imago pada ketiga kandang diperoleh dengan terlebih dahulu menyiapkan media PKM dan difermentasi selama 2 hari. Media tersebut dimasukkan ke dalam wadah plastik kecil kemudian daun pisang kering diletakkan di atas media sebagai wadah bagi BSF betina bertelur. Telur imago dipanen setiap 2 hari sekali, ditimbang, dan dicatat. Parameter yang digunakan selama penelitian disajikan pada Tabel 1 .

\begin{tabular}{|c|c|c|}
\hline Parameter & Peralatan & Waktu \\
\hline \multicolumn{3}{|l|}{ Telur BSF } \\
\hline 1. Waktu menetas telur & Visual & Peletakan di media \\
\hline \multicolumn{3}{|l|}{ Pertumbuhan Larva } \\
\hline 1. Panjang tubuh & Progam image-J & 2 hari $1 x$ \\
\hline 2. Lebar tubuh & Progam image-J & 2 hari $1 \mathrm{x}$ \\
\hline 3. Berat tubuh & $\begin{array}{l}\text { Timbangan } \\
\text { Digital }\end{array}$ & 2 hari $1 \mathrm{x}$ \\
\hline 4. Warna tubuh & Visual & 2 hari $1 x$ \\
\hline \multicolumn{3}{|l|}{ Faktor Lingkungan } \\
\hline 1. Suhu media & Thermometer & Setiap hari \\
\hline 2. $\mathrm{pH}$ media & $\mathrm{pH}$ meter & Setiap hari \\
\hline 3. Suhu udara & $\begin{array}{l}\text { Hygro- } \\
\text { thermometer }\end{array}$ & Setiap hari \\
\hline 4. Kelembaban udara & $\begin{array}{l}\text { Hygro } \\
\text { Thermometer }\end{array}$ & Setiap hari \\
\hline \multicolumn{3}{|l|}{ Fase Prepupa } \\
\hline 1. Munculnya prepupa & Visual & Setiap hari \\
\hline 2. Berat Biomassa segar & $\begin{array}{l}\text { Timbangan } \\
\text { Digital }\end{array}$ & $50 \%$ sudah prepupa \\
\hline \multicolumn{3}{|l|}{ Fase Pupa } \\
\hline 1. Munculnya pupa & Visual & Setiap hari \\
\hline \multicolumn{3}{|l|}{ Fase Imago } \\
\hline $\begin{array}{l}\text { 1. Waktu muncul ima- } \\
\text { go dari pupa }\end{array}$ & Visual & Setiap hari \\
\hline $\begin{array}{l}\text { Fase Telur Dalam } \\
\text { Kandang }\end{array}$ & & \\
\hline 1. Jumlah telur & Visual & Panen telur \\
\hline 2. Berat telur & $\begin{array}{l}\text { Timbangan } \\
\text { digital dan } \\
\text { analitik }\end{array}$ & Panen telur \\
\hline
\end{tabular}

Komposisi nilai gizi ditentukan dengan analisis proksimat. Uji proksimat merupakan analisis kimiawi pada pakan/bahan menghasilkan kadar air, abu, protein kasar, lemak kasar dan serat kasar. Analisis kadar air menggunakan metode pengeringan dalam oven pada suhu $105{ }^{\circ} \mathrm{C}$ selama beberapa waktu. Analisis kadar abu menggunakan metode pembakaran dalam tungku/tanur pada suhu $500-600{ }^{\circ} \mathrm{C}$. Protein kasar merupakan kandungan nitrogen pakan/ransum dikalikan faktor protein rata-rata (6.25), dan kadar protein kasar tersebut ditentukan dengan metode Kjeldahl ( $\mathrm{N}$ x 6.25) dengan $\mathrm{N}$ adalah kadar nitrogen. Kadar lemak kasar menggunakan metode ekstraksi soxhlet, dan kadar serat kasar menggunakan metode Van Soest (asam-basa) (PBMT, 2012). Larva BSF dibawa ke laboratorium Pusat Penelitian Sumberdaya Hayati dan Bioteknologi Lembaga Penelitian dan Pemberdayaan Masyarakat IPB untuk uji proksimat.

\subsubsection{Analisis Data}

Data yang diperoleh disajikan dalam bentuk tabel dan grafik kemudian dianalisis secara deskriptif. Analisis data menggunakan ANOVA pada taraf 5\%. Apabila terdapat pengaruh nyata maka dilakukan uji lanjut 
untuk mengetahui perbedaan antar perlakuan yaitu Uji Duncan pada taraf kepercayaan 95\% (P<0.05). Data diolah menggunakan program software SPSS.

\section{Hasil dan Pembahasan}

\subsection{Pertumbuhan Larva BSF (Hermetia illucens L.)}

Pertumbuhan BSF diawali sejak telur menetas menjadi larva. Hasil penelitian menunjukkan telur menetas mencapai lebih dari $95 \%$ pada hari ke-3 setelah peletakan telur di media kultur dan memasuki fase aktif makan. Fase larva berlangsung selama 12-13 hari. Selama fase makan, larva mengalami pertumbuhan panjang, lebar, dan bobot hingga fase pupa (Tabel 2). Sampah restoran merupakan media yang sangat baik untuk mendukung pertumbuhan BSF karena memiliki jenis sampah makanan yang sangat beragam dari produk hewani, nabati, nasi, dan rerotian.

Tabel 2. Pertumbuhan larva BSF

\begin{tabular}{ccccc}
\hline \multirow{2}{*}{ Parameter } & Satuan & \multicolumn{3}{c}{ Perlakuan } \\
\cline { 3 - 5 } & & $\mathrm{A}$ & $\mathrm{B}$ & $\mathrm{C}$ \\
\hline Panjang & $\mathrm{mm}$ & $16.38 \pm 2.59^{\mathrm{b}}$ & $16.44 \pm 2.70^{\mathrm{b}}$ & $15.85 \pm 2.12^{\mathrm{a}}$ \\
Lebar & $\mathrm{mm}$ & $4.20 \pm 0.71^{\mathrm{b}}$ & $4.22 \pm 0.70^{\mathrm{b}}$ & $4.05 \pm 0.59^{\mathrm{a}}$ \\
Bobot & $\mathrm{g}$ & $0.11 \pm 0.04^{\mathrm{b}}$ & $0.10 \pm 0.04^{\mathrm{b}}$ & $0.09 \pm 0.03^{\mathrm{a}}$
\end{tabular}

Keterangan: Perlakuan $\mathrm{A}=300 \mathrm{~kg}$ sampah organik restoran ditambah $6 \%$ silase ikan, Perlakuan $\mathrm{B}=300 \mathrm{~kg}$ sampah organik restoran ditambah 6\% darah sapi, Perlakuan $\mathrm{C}=300 \mathrm{~kg}$ sampah organik restoran tanpa penambahan. Huruf superscript yang berbeda menunjukkan hasil berbeda nyata pada taraf uji $5 \%$.

Tabel 2 menunjukkan panjang larva BSF pada ketiga perlakuan memiliki kisaran dari 15.85-16.44 mm, lebar 4.05-4.22 $\mathrm{mm}$ dan bobot tubuh 0.09-0.11 mg. Secara statistik menunjukkan bahwa panjang, lebar dan bobot larva pada perlakuan A dan B berbeda nyata dengan perlakuan $\mathrm{C}(\mathrm{P}<0.05)$ menunjukkan bahwa perlakuan A dan B memiliki nilai lebih tinggi dibandingkan pada perlakuan C. Hal ini menunjukkan pemberian silase ikan dan darah sapi memberikan pengaruh yang baik terhadap pertumbuhan panjang, lebar dan bobot tubuh larva. Gobbi et al. (2013) dan Tomberlin et al. (2002) mengemukakan kualitas dan kuantitas makanan yang dicerna oleh larva BSF memiliki pengaruh penting terhadap pertumbuhan dan waktu perkembangan larva, kelangsungan hidup, mortalitas dan perkembangan ovarium serangga dewasa serta menentukan perkembangan fisiologi dan morfologi BSF dewasa.

Fase larva BSF dijadikan sebagai landasan untuk mengelompokkan larva sebagai agen biokonversi berbagai limbah organik karena sebagian besar fase hidupnya berperan sebagai dekomposer (Fahmi, 2015). Dengan demikian, larva berpotensi mampu mengkonversi limbah/sampah organik dalam jumlah besar menjadi biomassa kaya protein untuk mengganti tepung ikan (Diener et al., 2009a). Pertumbuhan larva selama fase aktif makan bergantung pada jumlah dan jenis limbah organik yang diberikan. Pertumbuhan BSF menggunakan media yang berbeda telah dilaporkan antara lain pada media PKM menghasilkan panjang larva 6.9-19.9 mm, lebar 2.0-5.5 mm, dan bobot 0.01-0.18 gr (Rachmawati et al., 2010). Pada media sampah dapur (kitchen waste) memiliki kandungan lemak, kalori dan energi paling besar sehingga menghasilkan bobot larva $679.88 \mathrm{mg}$ per 3 larva dan panjang tubuh $2.22 \mathrm{~cm}$ (Nguyen et al., 2015). Pada media kombinasi sampah organik restoran dengan feses memiliki bobot prepupa 221-224 mg (Dortmants, 2015). Sementara pada media kotoran sapi dengan jeroan ikan memiliki bobot 0.10-0.16 g (St-Hilaire et al., 2007a). Kim et al. (2010) mengemukakan bahwa larva dapat mencapai panjang hingga $20 \mathrm{~mm}$, lebar 6 $\mathrm{mm}$ dan berat larva meningkat secara dramatis dari larva instar ke-3 sampai ke-6.

\subsection{Pengamatan Fase Prepupa dan Pupa BSF}

Larva BSF memasuki fase prepupa dicirikan dengan adanya perubahan warna tubuh larva yaitu kekuningan, coklat kekuningan, coklat muda sampai coklat gelap. Selain itu, pergerakan larva yang sebelumnya sangat aktif berangsur-angsur menjadi tidak aktif atau melambat. Hal ini disebabkan larva telah memasuki fase tidak aktif makan dengan meninggalkan residu makanan menuju tempat kering. Fase prepupa berlangsung selama 6 hari. Selanjutnya fase prepupa bermetamofosis menjadi fase pupa dicirikan dengan adanya perubahan warna tubuh yaitu coklat gelap sampai hitam legam. Selain itu, pergerakan tubuh prepupa yang melambat berangsur-angsur tidak bergerak (pasif) dengan tekstur kulit pupa lebih keras, berkerut serta bobot tubuh lebih ringan. Fase pupa berlangsung selama 6 hari (Tabel 3).

Tahap akhir larva, disebut prepupa, merupakan fase tidak makan lagi dan bermigrasi dari sumber makanan mencari tempat kering dan tempat terlindungi untuk memasuki tahap pupa (Diener et al., 2011b). Selain itu, pada tahap prepupa juga merupakan tahap berada pada ukuran maksimum dengan penyimpanan lemak yang banyak sebagai cadangan makanan sampai menjadi serangga dewasa (Newton et al., 2005a). Prepupa dapat dengan mudah dipanen dan digunakan sebagai bahan pakan berharga dalam budidaya perikanan, peternakan ayam dan hewan ternak lainnya (Diener et al. 2009a, Newton et al. 2005a).

Tabel 3. Deskripsi persentase munculnya prepupa dan pupa berdasarkan pengamatan secara visual

\begin{tabular}{|c|c|c|c|c|}
\hline \multirow[t]{2}{*}{ Parameter } & \multirow{2}{*}{$\begin{array}{l}\text { Umur } \\
\text { (hari) }\end{array}$} & \multicolumn{3}{|c|}{ Perlakuan } \\
\hline & & A & $\mathrm{B}$ & $\mathrm{C}$ \\
\hline \multirow[t]{4}{*}{ Prepupa } & 12 & $\begin{array}{l}\text { Mulai mun- } \\
\text { cul warna } \\
\text { kekuningan, } \\
\text { kuning } \\
\text { kecoklatan } \\
\text { dan coklat }\end{array}$ & $\begin{array}{l}\text { Mulai mun- } \\
\text { cul warna } \\
\text { kekuningan, } \\
\text { kuning } \\
\text { kecoklatan } \\
\text { dan coklat }\end{array}$ & $\begin{array}{l}\text { Mulai mun- } \\
\text { cul warna } \\
\text { kekuningan, } \\
\text { kuning } \\
\text { kecoklatan } \\
\text { dan coklat }\end{array}$ \\
\hline & 15 & $\begin{array}{l}40 \% \text { coklat } \\
\text { masih } \\
\text { bercampur } \\
\text { dengan }\end{array}$ & $\begin{array}{l}50 \% \text { coklat } \\
\text { lebih merata }\end{array}$ & $\begin{array}{l}40 \% \text { coklat } \\
\text { masih } \\
\text { bercampur } \\
\text { dengan }\end{array}$ \\
\hline & & larva putih & & larva putih \\
\hline & 17 & $90 \%$ coklat & $95 \%$ coklat & \\
\hline Pupa & 16 & - & Muncul & - \\
\hline
\end{tabular}




\begin{tabular}{llll}
\hline & & pupa & \\
17 & Muncul & - & $\begin{array}{l}\text { Muncul } \\
\text { pupa }\end{array}$ \\
21 & - & $95 \%$ & - \\
22 & $90 \%$ & - & $85 \%$ \\
\hline
\end{tabular}

Larva yang telah mencapai sekitar $50 \%$ prepupa yaitu pada umur 15 hari mulai dipanen, ditimbang dan dipindahkan ke wadah fiberglass untuk memasuki fase pupa (Tabel 4).

Tabel 4. Produksi prepupa pada setiap perlakuan

\begin{tabular}{lcccc}
\hline \multirow{2}{*}{ Parameter } & Satuan & \multicolumn{3}{c}{ Perlakuan } \\
\cline { 3 - 5 } & & $\mathrm{A}$ & $\mathrm{B}$ & $\mathrm{C}$ \\
\hline Prepupa & $\mathrm{kg}$ & 44.3 & 47.2 & 36.7 \\
\hline
\end{tabular}

Fahmi (2015) melaporkan telur serangga BSF menetas setelah 3-6 hari, tahap larva 3-4 minggu, pupa mencapai tahap dewasa sekitar 1 minggu dan masa hidup dewasa 1-2 minggu. Hasil penelitian Diener et al. (2011a) menunjukkan waktu perkembangan BSF (H.illucens) dari telur sampai prepupa pada pakan ayam 15.9-32.7 hari, limbah feses 27 hari, kombinasi limbah feses dengan sampah pasar $(\mathrm{FS}: \mathrm{MW}=1: 1) 18$ hari dan sampah pasar 18 hari. Selanjutnya, Rachmawati et al. (2010) melaporkan tahapan larva kurang lebih 12 hari, larva mengalami perubahan warna menjadi coklat dan semakin gelap 1 minggu kemudian. Tahapan prepupa hari ke-19, pupa hari ke-24 dan berlangsung selama 8 hari.

\subsection{Koloni Imago BSF}

Jumlah pupa berkisar dari 12.000 sampai 13.000 ekor. Pupa mulai menetas menjadi imago pada umur 21 hari di ketiga kandang dan 4 hari berikutnya telah terlihat imago memadati kandang baru. Fase imago berlangsung selama 15 hari. Imago yang telah menetas mulai terbang dan aktif. Selama periode pengamatan, aktivitas serangga terlihat mulai pukul 08.00 dan sangat aktif mulai pukul 09.00 pagi sampai 14.00 siang dengan suhu kandang berkisar antara $30{ }^{\circ} \mathrm{C}$ sampai 40 ${ }^{\circ} \mathrm{C}$ dengan kelembaban 27-60 \%, selanjutnya pada sore hari aktivitas imago berangsur-angsur mulai menurun. Imago BSF sangat membutuhkan kondisi lingkungan di bawah sinar matahari penuh karena pada kondisi tersebut aktivitas imago sangat baik dan aktif untuk mendukung aktivitas kawin dan bertelur. Selanjutnya, imago mulai kawin antara hari ke-5 dan ke-6 setelah pupa menetas.

Tomberlin dan Sheppard (2002) mengemukakan perilaku kawin dan bertelur dimediasi oleh syarat lingkungan dan waktu (time of day). Waktu dan intensitas cahaya matahari memainkan peran utama dalam menentukan waktu dan jumlah serangga BSF dewasa akan kawin, sedangkan waktu, suhu dan kelembaban secara signifikan berkorelasi dengan perilaku bertelur. Pasangan serangga BSF kawin 75\% ketika intensitas cahaya lebih besar dari $200 \mu \mathrm{mol} \mathrm{m} \mathrm{m}^{-1}$ dan aktivitas kawin lebih sering terjadi pagi hari. Zhang et al., (2010) juga melaporkan bahwa aktivitas kawin paling banyak terjadi pada pagi hari $(85 \%)$ pada kondisi di bawah sinar matahari mulai pukul 08:30 dan memuncak pada pukul 10:00 pada intensitas cahaya sekitar $110 \mu \mathrm{mol} \mathrm{m}{ }^{-2} \mathrm{~s}^{-1}$. Diener et al. (2011a) berhasil membentuk koloni BSF yang stabil. Suhu siang hari $31.8^{\circ} \mathrm{C}$ adalah kondisi optimal untuk reproduksi, dan serangga $H$. illucens toleran terhadap berbagai suhu (kisaran 15 sampai $47^{\circ} \mathrm{C}$ ). Sheppard et al. (2002) juga mengemukakan serangga dewasa biasanya kawin dan bertelur pada suhu $24-40{ }^{\circ} \mathrm{C}$ atau lebih dengan kelembaban $30-90 \%$.

Imago mulai bertelur pada hari ke-7 setelah pupa menetas (BSF umur 27 hari) dan meletakkan telur di setiap lipatan daun pisang kering. Pada hari ke- 8 telur mulai dipanen secara berkala setiap 2 hari sekali dan berakhir pada hari ke-15 (BSF umur 36 hari) ditandai kondisi semua imago dalam kandang sudah mati. Telur imago yang dipanen dari ketiga kandang pengamatan menghasilkan bobot telur berkisar dari 2.03 sampai 2.88 gram (Tabel 5).

Tabel 5. Telur yang dihasilkan oleh imago BSF (H.illucens) dalam kandang pengamatan

\begin{tabular}{cccc}
\hline \multicolumn{4}{c}{ kandang pengamatan } \\
Hari ke- & Kandang 1 & Kandang 2 & Kandang 3 \\
\hline 1 & 0.14 & 0.50 & 0.30 \\
3 & 0.56 & 0.87 & 0.64 \\
5 & 0.89 & 0.91 & 0.84 \\
7 & 0.94 & 0.50 & 0.20 \\
9 & 0.11 & 0.10 & 0.05 \\
\hline Total & 2.64 & 2.88 & 2.03 \\
\hline
\end{tabular}

Rata-rata jumlah telur BSF dalam $0.01 \mathrm{~g}$ pada kandang 1 (486 butir), kandang 2 (459 butir), dan kandang 3 (492 butir) sehingga bobot per butir telur BSF adalah berkisar dari 0.020 sampai $0.022 \mathrm{mg} / \mathrm{butir}$. Istirokhah (2012) melaporkan pupa sebanyak $2 \mathrm{~kg}$ dengan jumlah pupa \pm 14.000 ekor yang akan menjadi imago menghasilkan bobot telur rata-rata $19.01 \mathrm{~g}$. Dalam penelitian ini, jumlah telur yang dihasilkan oleh imago dari ketiga kandang masih tergolong rendah. Hal ini kemungkinan dapat disebabkan oleh beberapa faktor yaitu ukuran tubuh imago betina, ukuran kandang cukup kecil dan setiap panen telur terdapat telur diletakkan oleh imago betina di media PKM yang sudah mengering dan lengket pada media tersebut sehingga tidak bisa dipanen. Jumlah imago yang sangat padat dengan ukuran kandang cukup kecil, menyebabkan imago tidak memiliki ruang pergerakan leluasa untuk melakukan aktivitas kawin dan juga dapat menyebabkan stress bagi imago. Faktor tersebut kemungkinan dapat mempengaruhi jumlah imago yang kawin dan bertelur.

Tomberlin (2001) mengemukakan koloni imago BSF tanpa pemberian air menyebabkan imago mengalami dehidrasi dan kurang kuat sehingga tidak dapat bereproduksi secara efektif dan tidak semangat bertelur. Serangga BSF bereproduksi tanpa makan dan mengandalkan cadangan lemak yang diperoleh selama fase larva untuk kelangsungan hidup serangga dewasa 
dan produksi telur. Ukuran kandang serangga BSF (2 x 2 x $3 \mathrm{~m}^{3}$ ) berisi 500 imago menghasilkan $72 \%$ pasangan serangga BSF kawin. Dalam waktu 2 hari setelah kawin ditemukan dalam tubuh serangga betina telah terbentuk telur dengan sempurna. Jumlah telur yang dihasilkan per individu berkisar dari 206-639 butir dengan berat per individu telur berkisar dari 0.023 - $0.025 \mathrm{mg}$. Sheppard et al. (2002) menemukan kondisi yang mendukung aktivitas kawin serangga BSF ( $H$. illucens) yang dapat diandalkan yaitu ukuran kandang ( $\left.2 \times 2 \times 4 \mathrm{~m}^{3}\right)$, memiliki ketersediaan intensitas cahaya matahari dan ruang udara yang cukup. Selanjutnya Alvarez (2012) mengatakan keberhasilan proses kawin bergantung pada intensitas cahaya, panjang paparan cahaya dan panjang gelombang serta kepadatan serangga dewasa dalam ruang aktivitas kawin. Dengan demikian dapat mempengaruhi produksi telur yang dihasilkan oleh imago.

\subsection{Hasil Pengukuran Suhu dan pH Media}

Suhu dan $\mathrm{pH}$ media berperan penting dalam proses biokonversi sampah organik oleh larva dalam mempercepat pengomposan dan mendukung pertumbuhan larva. Pengukuran suhu dan $\mathrm{pH}$ media mulai dilakukan ketika larva dipindahkan ke wadah perlakuan. Suhu media pada ketiga perlakuan berkisar dari 36.548-38.058 ${ }^{\circ} \mathrm{C}$, dan $\mathrm{pH}$ media 6.635-6.62 masih dalam kisaran $\mathrm{pH}$ netral (Tabel 6). Secara statistik menunjukkan bahwa suhu media pada perlakuan A berbeda nyata dengan perlakuan $\mathrm{B}$ dan $\mathrm{C}(\mathrm{P}<0.05)$ akan tetapi $\mathrm{pH}$ media tidak berbeda nyata $(\mathrm{P}>0.05)$ pada ketiga perlakuan. Aktivitas larva selama fase makan sangat aktif dan lahap sehingga suhu tubuh larva mempengaruhi peningkatan suhu media. Selain itu, suhu dan kelembaban udara dalam kandang larva berkisar dari 28.83 sampai $31.93{ }^{\circ} \mathrm{C}$ dan 62.22 sampai $83.44 \%$ dapat mempengaruhi suhu media. Larva mengeluarkan energi untuk mengkonsumsi sampah restoran yang sangat beragam (heterogen) dan dalam kondisi tidak digiling atau dicacah. Kondisi ini menyebabkan suhu media cukup tinggi Seperti dikatakan oleh Caruso et al. (2014) bahwa larva memiliki mulut kuat untuk tujuan makan.

Tabel 6. Pengukuran suhu dan $\mathrm{pH}$ media pertumbuhan larva BSF

\begin{tabular}{cccc}
\multicolumn{3}{c}{ (Hermetia illucens $\mathrm{L})}$. \\
\hline Parameter & $\mathrm{3}$ & \multicolumn{3}{c}{ Perlakuan } \\
\cline { 2 - 4 } & $\mathrm{B}$ & $\mathrm{C}$ \\
\hline Suhu $\left({ }^{\circ} \mathrm{C}\right)$ & $38.06 \pm 2.816^{\mathrm{b}}$ & $37.22 \pm 2.845^{\mathrm{a}}$ & $36.55 \pm 3.001^{\mathrm{a}}$ \\
$\mathrm{pH}$ & $6.62 \pm 0.311^{\mathrm{a}}$ & $6.64 \pm 0.3^{\mathrm{a}}$ & $6.64 \pm 0.326^{\mathrm{a}}$
\end{tabular}

Keterangan: Perlakuan $\mathrm{A}=300 \mathrm{~kg}$ sampah organik restoran ditambah $6 \%$ silase ikan, Perlakuan $\mathrm{B}=300 \mathrm{~kg}$ sampah organik restoran ditambah $6 \%$ darah sapi, Perlakuan $\mathrm{C}=300 \mathrm{~kg}$ sampah organik restoran tanpa penambahan. Huruf superscript yang berbeda menunjukkan hasil berbeda nyata pada taraf uji $5 \%$.

Larva BSF (H. illucens) mampu mentolerir sejumlah inhibitor biologi dalam lindi microaerobic fermentation (MF) termasuk etanol, asetat, suhu dan $\mathrm{pH}$ ekstrim. Larva BSF toleran terhadap tingkat $\mathrm{pH}$ 0.7-13.7 dan mampu mengubah $\mathrm{pH}$ awal dari 2.7 sam- pai 12.7 menjadi antara 7.8 dan 8.9 sehingga cocok digunakan dalam bioteknologi pengolahan lindi (Alattar, 2012). Selain itu, larva BSF juga sangat resisten dan mampu bertahan terhadap kondisi lingkungan, seperti kekeringan, kekurangan makanan atau kekurangan oksigen (Diener et al., 2011b). Hasil penelitian Liu et al. (2008) melaporkan bahwa suhu secara signifikan mempengaruhi kemampuan larva BSF dalam mengurangi jumlah $E$. coli, keberhasilan terbesar dipelihara pada suhu $27{ }^{\circ} \mathrm{C}$ dan $31{ }^{\circ} \mathrm{C}$. Erikson et al. (2004) menambahkan pertumbuhan terbesar larva BSF (H.illucens) dalam kotoran ayam, kotoran babi dan kotoran sapi optimal pada suhu 27 ${ }^{\circ} \mathrm{C}$. Pengurangan populasi E. coli $\mathrm{O} 157: \mathrm{H} 7$ dalam kotoran ayam oleh larva dipengaruhi oleh suhu penyimpanan $27^{\circ} \mathrm{C}$ atau $32^{\circ} \mathrm{C}$. Lebih lanjut, Sheppard et al. (2002) mengemukakan telur dan larva umumnya dipelihara pada suhu $27{ }^{\circ} \mathrm{C}$ tetapi juga tampaknya mentolerir berbagai kondisi lingkungan.

\subsection{Kompos BSF}

Larva BSF sangat cepat mendekomposisi sampah restoran hingga pada tahap akhir (prepupa) dan berlangsung selama 10-11 hari pada ketiga perlakuan. Residu akhir yang dihasilkan oleh larva antara lain kompos yaitu hasil metabolisme larva BSF (ekskresi dan sekresi) dan residu kasar. Pada akhir pengamatan dilakukan panen kompos dan residu kasar pada ketiga perlakuan (Tabel 7). Kompos yang dihasilkan oleh larva BSF memiliki karakteristik yang sama yaitu berwarna hitam, tekstur kasar, berbentuk butiran dan memiliki bau khas kotoran larva. Sementara residu kasar merupakan bagian sampah organik yang memiliki tekstur keras sehingga tidak dapat dicerna oleh larva selama fase makan. Larva lebih menyukai sampah organik yang memiliki tekstur lunak.

Tabel 7. Total bobot residu yang dihasilkan oleh larva

\begin{tabular}{ccccc}
\hline \multirow{2}{*}{ Parameter } & \multirow{2}{*}{ Satuan } & \multicolumn{3}{c}{ Perlakuan } \\
\cline { 3 - 5 } & & $\mathrm{A}$ & $\mathrm{B}$ & $\mathrm{C}$ \\
\hline Kompos & $\mathrm{kg}$ & 19.1 & 19.2 & 18.4 \\
Residu kasar & $\mathrm{kg}$ & 10.0 & 9.5 & 9.6 \\
\hline
\end{tabular}

Hasil penelitian Anggraeni (2010) melaporkan bahwa pemupukan menggunakan kompos larva BSF yang disebut Biokonversion Fertilizer Palm Kernel Meal (BFPKM) pada tanaman kacang panjang (Vigna unguiculata L. Walp.) varietas Mutiara cenderung memberikan pengaruh positif terhadap pertumbuhan vegetatif maupun generatif tanaman. Unsur hara yang terdapat pada BFPKM mampu meningkatkan panjang batang, jumlah cabang batang, jumlah daun, luas permukaan daun, kandungan klorofil, jumlah bunga, jumlah buah, dan panjang buah. BFPKM mengandung $15.7 \%$ C-organik, $3 \%$ N, $0.82 \% \mathrm{P}$ dan $1.04 \% \mathrm{~K}$. Menurut Gabler (2014) bahwa pemanfaatan BSF sebagai strategi pengelolaan limbah/sampah organik merupakan strategi inovatif karena dapat menghasilkan pakan ternak yang mengandung lemak dan protein melimpah dan pupuk organik. 


\subsection{Analisis Proksimat Kandungan Nutrisi Larva BSF}

Larva BSF memiliki kemampuan yang baik untuk mendegradasi limbah organik diindikasi oleh kandungan nutrisi dari larva BSF (Fahmi, 2015). Oleh karena itu, kualitas nutrisi dari makanan yang diberikan kepada larva BSF sangat penting dan pengaruhnya terhadap masa tubuh dan/atau ukuran individu. Hal tersebut memungkinkan untuk memaksimalkan produksi telur secara masal yang berkesinambungan dalam budidaya BSF (Gobbi et al., 2013), Selain kualitas makanan juga perlu memperhatikan ketersediaan kuantitas makanan yang diberikan. Kandungan nutrisi larva BSF pada ketiga perlakuan memiliki kadar protein berkisar dari $31.44 \%$ sampai $33.88 \%$, kadar lemak berkisar dari $30.07 \%$ sampai $34.39 \%$ (Gambar 1).

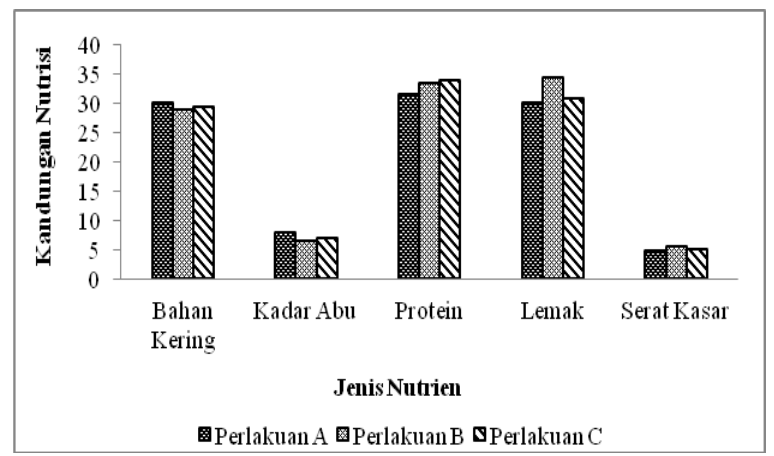

Gambar 1. Kandungan nutrisi larva BSF

Zheng et al. (2012) melaporkan kandungan lemak tinggi serangga $\mathrm{BSF}$ (H. illucens) mengandung lemak tinggi memiliki potensi sebagai bahan baku murah untuk produksi biodiesel menggunakan media sampah restoran dan sebagian besar sifat bahan bakarnya sesuai dengan standar Eropa EN 14214. St-Hilaire et al. (2007a) mengemukakan larva BSF (H. illucens) mampu "mendaur ulang" proporsi minyak ikan dari jeroan ikan dan memiliki 30\% lipid dan 3\% sehingga dapat menggantikan tepung ikan dan minyak ikan yang digunakan sebagai pakan ikan. Beberapa hasil penelitian mengenai kandungan nutrisi larva BSF menggunakan media yang berbeda disajikan dalam Tabel 8.

Tabel 8. Kandungan nutrisi larva BSF (H. illucens) berdasarkan sumber makanan yang berbeda

\begin{tabular}{|c|c|c|c|}
\hline \multicolumn{2}{|c|}{ Jenis nutrien } & \multirow{2}{*}{$\begin{array}{c}\text { Jenis } \\
\text { Makanan }\end{array}$} & \multirow{2}{*}{$\begin{array}{l}\text { Sumber } \\
\text { Literatur }\end{array}$} \\
\hline Protein & Lemak & & \\
\hline $21.20 \mathrm{~g}$ & NA & Sampah dapur & $\begin{array}{l}\text { Nguyen } \\
\text { et al. }(2015)\end{array}$ \\
\hline $12.9 \mathrm{~g}$ & $2.22 \mathrm{~g}$ & $\begin{array}{l}\text { Buah-buahan dan } \\
\text { sayur-sayuran }\end{array}$ & $\begin{array}{l}\text { Nguyen } \\
\text { et al. }(2015)\end{array}$ \\
\hline $19.4 \mathrm{~g}$ & $11.60 \mathrm{~g}$ & Limbah ikan & $\begin{array}{l}\text { Nguyen } \\
\text { et al. }(2015)\end{array}$ \\
\hline $58.62 \%$ & $13 \%$ & PKM & Fahmi (2015) \\
\hline $60.56 \%$ & $13.56 \%$ & $\begin{array}{l}\text { PKM+Limbah } \\
\text { Pasar+Limbah } \\
\text { Ikan }\end{array}$ & Fahmi (2015) \\
\hline $49.08 \%$ & $21.14 \%$ & PKM & Ardianti (2011) \\
\hline $44.86 \%$ & $30.34 \%$ & $\begin{array}{l}\text { PKM+Silase } \\
\text { Ikan Fermentasi }\end{array}$ & Ardianti (2011) \\
\hline $47.56 \%$ & $19.80 \%$ & PKM & Rachmawati \\
\hline
\end{tabular}

\begin{tabular}{|c|c|c|c|}
\hline & & & et al. (2010) \\
\hline $\begin{array}{l}34.9- \\
42.4 \%\end{array}$ & - & $\begin{array}{l}\text { Pakan ayam } \\
\text { (chicken feed) }\end{array}$ & $\begin{array}{l}\text { Diener } \\
\text { et al. }(2009 \mathrm{~b})\end{array}$ \\
\hline $43.6 \%$ & $33.1 \%$ & Kotoran babi & $\begin{array}{l}\text { St-Hilaire } \\
\text { et al. }(2007 \mathrm{~b})\end{array}$ \\
\hline $42.0 \%$ & $35.0 \%$ & Kotoran ayam & Sheppard (1994) \\
\hline
\end{tabular}

\section{Kesimpulan}

Larva BSF Hermetia illucens (Diptera: Stratiomyidae) sangat cocok digunakan sebagai teknologi pengolahan berbagai sampah organik berbasis serangga. Teknologi ini adalah salah satu bentuk pengelolaan sampah melalui konsep 3R dalam rangka meminimalkan volume sampah organik dari sumbernya. Larva BSF mampu mendekomposisi sampah organik selama 10-11 hari dengan menghasilkan nilai tambah berupa kompos, dan biomassa larva atau prepupa berpotensi sebagai pakan bernutrisi baik. Larva memiliki kandungan protein $31.44-33.88 \%$ dan lemak 30.07$34.39 \%$ dapat digunakan untuk pakan ikan dan hewan ternak lainnya. Penambahan pakan silase ikan dan darah sapi pada larva BSF memberikan pengaruh positif terhadap pertumbuhan larva meskipun belum menghasilkan pertumbuhan maksimal dengan dosis yang diberikan pada penelitian ini. Disarankan agar dikaji lebih detil takaran yang tepat antara kebutuhan telur atau bobot larva dengan jumlah sampah organik serta dosis pakan tambahan untuk mendapatkan produksi larva, prepupa dan telur BSF paling baik dalam skala produksi masal.

\section{Daftar Pustaka}

[1] [BPS] Badan Pusat Statistik, 2012. Statistik Ekspor Hasil Perikanan Menurut Komoditi, Provinsi Dan Pelabuhan Asal Ekspor. Pusat Data, Statistik, dan Informasi Sekretariat Jenderal, Kementerian Kelautan dan Perikanan, Jakarta.

[2] [KLHK] Kementerian Lingkungan Hidup dan Kehutanan, 2015. Rangkaian hari lingkungan hidup 2015-dialog penanganan sampah plastik [terhubung berkala].

[3] [UU] Undang-undang Republik Indonesia, 2008. Undangundang Republik Indonesia Nomor 18 Tahun 2008 tentang Pengelolaan sampah. Sekretariat Negara, Jakarta.

[4] Alattar, M. A. 2012. Biological treatment of leachates of microaerobic fermentation. Theses. Portland State University, Portland.

[5] Alvarez, L. 2012. The role of black soldier fly, Hermetia illucens (L.) (Diptera: Stratiomyidae) in sustainable waste management in Northern Climates. Dissertations. University of Windsor, Windsor.

[6] Anggraeni, D. 2010. Pengaruh pemupukan bioconversion fertilizer palm kernel meal (BFPKM) terhadap pertumbuhan Vigna unguiculata L. Walp (Kacang Panjang) varietas Mutiara. Tesis. Program Pascasarjana, Universitas Indonesia, Depok.

[7] Ardianti, D. 2011. Perkembangan dan fekunditas serangga Hermetia illucens (Stratiomyidae, Diptera) yang diberi pakan bungkil kelapa sawit yang diperkaya. Skripsi. Institut Pertanian Bogor, Bogor.

[8] Bonso, N.K .2013. Bioconversion of organic fraction of solid waste using the larvae of the black soldier fly (Hermentia illucens). Thesis. Kwame Nkrumah University of Science and Technology, Kumasi, Ghana.

[9] Caruso, D., E. Devic, I. W. Subamia, P. Talamond, dan E. Baras, 2014. Technical Handbook of Domestification and Production of Diptera Black Soldier Fly (BSF) Hermetia illucens, Stratiomyidae. IRD editions, Bogor.

[10] Cheng, H., Y. Hu, 2010. Municipal solid waste (MSW) as a renewable source of energy: Current and future practices in China. Bioresource technology. 10: 3816-3824. 
[11] Davis, S.C., W. Hay, dan J. Pierce, 2014. Biomass in the energy industry: An introduction. London (GB): BP p.l.c.

[12] Diener, S.,C. Zurbrügg, dan K. Tockner, 2009b. Conversion of organic material by black soldier fly larvae: establishing optimal feeding rates. Waste Management Research 27, pp. 603-610.

[13] Diener, S., C. Zurbrügg, F. R. Gutiérrez, D. H. Nguyen, A. Morel, T. Koottatep, dan K. Tockner, 2011b. Black soldier fly larvae for organic waste treatment-prospects and constraints. Dalam: Alamgir M., Q. H. Bari, I. M. Rafizul, S. M. T. Islam, G Sarkar, dan M. K. Howlader, editor. Proceedings of the WasteSafe 2011-2nd International Conference on Solid Waste Management in Developing Countries; 2011 Feb 1315; Khulna, Bangladesh, pp. 52-59.

[14] Diener, S., F. R. Gutiérrez, C. Zurbrügg, dan K. Tockner 2009a. Are larvae of the black soldier fly-Hermetia illucensa financially viable option for organic waste management in Costa Rica?. Proceedings Sardinia 2009, twelfth international waste management and landfill symposium. CISA publisher. Cagliari, Italy.

[15] Diener, S., M. Nandayure, S. Solano, F. R. Gutiérrez, C. Zurbrügg, dan K. Tockner, 2011a. Biological treatment of municipal organic waste using black soldier fly larvae. Waste Biomass Valor 2, pp. 357363.doi:10.1007/s.12649.011.9079.1.

[16] Dortmans, B. 2015. Valorisation of organic waste-Effect of the feeding regime on process parameters in a continuous black soldier fly larvae composting system. Theses. Swedish University of Agricultural Sciences, Swedish.

[17] Erickson, M.C., M. Islam, C. Sheppard, J. Liao, dan M. P. Doyle, 2004. Reduction of Escherichia coli O157:H7 and Salmonella enterica serovar enteritidis in chicken manure by larvae of the black soldier fly. Journal of Food Protection 67 (4), pp. 685-690.

[18] Fahmi, M. R., 2015. Optimalisasi proses biokonversi dengan menggunakan mini-larva Hermetia illucens untuk memenuhi kebutuhan pakan ikan. Pros sem nas masy biodiv indon 1(1), pp. 139-144.

[19] Gabler, F. 2014. Using black soldier fly for waste recycling and effective Salmonella spp. reduction. Theses. Swedish University of Agricultural Sciences, Swedish.

[20] Gani, A. 2007. Konversi sampah organik menjadi komarasca (kompos-arang aktif-asap cair) dan aplikasinya pada tanaman daun dewa. Disertasi. Sekolah Pascasarjana, Institut Pertanian Bogor, Bogor

[21] Gobbi, P., A. Martínez-Sánchez, dan S. Rojo, 2013. The effects of larval diet on adult life-history traits of the black soldier fly, Hermetia illucens (Diptera: Stratiomyidae). Eur J Entomol 110 (3), pp. 461-468.

[22] Istirokhah. 2012. Siklus hidup black soldier fly (Hermetia illucens) pada media bungkil kelapa sawit dengan penambahan silase ikan. Skripsi. Institut Pertanian Bogor, Bogor

[23] Kim, W., S. Bae, H. Park, K. Park, S. Lee, Y. Choi, S. Han, dan Y. Koh, 2010. The larval age and mouth morphology of the black soldier fly, Hermetia illucens (Diptera: Stratiomyidae). Int J Indust Entomol 21 (2), pp. 185-187.

[24] Li, Q., L. Zheng, H. Cai, E. Garza, Z. Yu, S. Zhou, 2011. From organic waste to biodiesel: black soldier fly, Hermetia illucens, makes it feasible. Fuel 90, pp. 1545-1548.

[25] Liu, Q., J. K. Tomberlin, J. A. Brady, M. R. Sanford, dan Z. $\mathrm{Yu}, 2008$. Black soldier fly (Diptera: Stratiomyidae) larvae reduce Escherichia coli in dairy manure. Environ Entomol 37 (6), pp. 1525-1530.

[26] Naryono, E. dan Soemarno, 2013. Perancangan sistem pemilahan, pengeringan, dan pembakaran sampah organik rumah tangga. Indonesian Green Technology Journal 2(1), pp. $27-$ 36.

[27] Newton, G. L., D. C. Sheppard, D. W. Watson, G. J. Burtle, C. R. Dove, J. K. Tomberlin, dan E. E. Thelen, 2005b. The black soldier fly, hermetia illucens, as amanure management/resource recovery tool.
[28] Newton, L., C. Sheppard, D. W. Watson, G. Burtle, dan R. Dove, 2005a. Using the black soldier fly, Hermetia illucens, as a value-added tool for the management of swine manure director of the animal and poultry waste management center, North Carolina state university, Raleigh, NC [terhubung berkala]. http://www.organicvaluerecovery.com [14 Maret 2016].

[29] Nguyen, T.T.X., J.K. Tomberlin, dan S. Vanlaerhoven, 2015. Ability of black soldier fly (Diptera: Stratiomyidae) larvae to recycle food waste. Environ Entomol 44 (2), pp. 406410.doi:10.1093/ee/nvv002.

[30] Rachmawati, D. Buchori, P. Hidayat, S. Hem, dan M. R. Fahmi, 2010. Perkembangan dan kandungan nutrisi larva Hermetia illucens (Linnaeus) (Diptera: Stratiomyidae) pada bungkil kelapa sawit. J Entomol Indon 7(1), pp. 28-41

[31] Sheppard, D.C., G.L. Newton, dan S.A. Thompson, 1994. A value added manure management system using the black soldier fly. Bioresour Technol 50 (1994), pp. 275-279.

[32] Sheppard, D.C., J.K. Tomberlin, J.A. Joyce, B.C. Kiser, dan S. M. Sumner, 2002. Rearing methods for the black soldier fly (Diptera: Stratiomyidae). J Med Entomol 39 (4), pp. 695698.

[33] St-Hilaire, S., C. Sheppard, J. K. Tomberlin, S. Irving, L. Newton, M. A. McGuire, E. E Mosley, R. W Hardy, dan W. Sealey, 2007b. Fly prepupae as a feedstuff for rainbow trout, Oncorhynchus mykiss. J World Aquacult Society 38 (1), pp. 59-67.

[34] St-Hilaire, S., K. Cranfill, M.A. McGuire, E.E. Mosley, J.K Tomberlin, L. Newton, W. Sealey, C. Sheppard, dan S. Irving, 2007a. Fish offal recycling by the black soldier fly produces a foodstuff high in omega-3 fatty acids. J World Aquacult Society 38 (2).

[35] Sudrajat, 2006. Mengelola sampah kota. Penebar Swadaya, Jakarta.

[36] Suriawiria, U., 2003. Mikrobiologi Air. PT Alumni, Bandung.

[37] Suyanto, E., E. Soetarto, Sumardjo, dan H. Hardjomidjojo, 2015. Model kebijakan pengelolaan sampah berbasis partisipasi "Green Community" mendukung kota hijau. Mimbar 31 (1), pp. 143-152.

[38] Tim Laboratorium, 2012. Pengetahuan bahan makanan ternak. Ilmu dan Teknologi Pakan Fakultas Peternakan IPB [terhubung berkala]. https://www.google.co.id/anuragaja.staff.ipb.ac.id/files/2012/ 04/Buku-PBMT [20 Februari 2017].

[39] Tomberlin, J.K., 2001. Biological, behavioral, and toxicological studies on the black soldier fly (Diptera:

[40] Tomberlin, J.K., D.C. Sheppard, 2002. Factors influencing mating and oviposition of black soldier flies (Diptera: Stratiomyidae) in a colony. J entomol sci 37 (4), pp. 345-352.

[41] Tomberlin, J.K., D.C. Sheppard, dan J. A. Joyce, 2002. Selected life-history traits of black soldier flies (Diptera: Stratiomyidae) reared on three artificial diets. Ann Entomol Soc Am 95 (3), pp. 379-386.

[42] Wibowo S., 2013. Karakteristik bio-oil serbuk gergaji sengon (Paraserianthes falcataria L. Nielsen) menggunakan proses pirolisis lambat. Jurnal Penelitian Hasil Hutan. 31(4):258270.

[43] Widyawidura W., J.I. Pongoh, 2016. Potensi waste to energy sampah perkotaan untuk kapasitas pembangkit $1 \mathrm{MW}$ di Propinsi DIY. J Mek Sist Termal. 1(1):21-25.

[44] Zhang, J., L. Huang, J. He, J.K. Tomberlin, J. Li, C. Lei, M. Sun, Z. Liu, dan Z. Yu, 2010. An artificial light source influences mating and oviposition of black soldier flies, Hermetia illucens. J Insect Sci 10 (202)

[45] Zheng, L., Q. Li, J. Zhang, dan Z. Yu, 2012. Double the biodiesel yield: Rearing black soldier fly larvae, Hermetia illucens, on solid residual fraction of restaurant waste after grease extraction for biodiesel production. Renewable energy 41 (2012), pp. 75-79. 